\title{
レシチン製剤の吸湿におよばす添加剤の影響*1
}

\author{
桜井正太郎, 林 佳子, 谷古宇秀, 杉原正泰 \\ 東京女子医科大学病院薬剂部 $* 2$
}

\section{Effect of Additives on Hygroscopicity of Lecithin Preparation*1}

\author{
Shotaro SAKURAI, KeIKo Hayashi, Shigeru Yakou, \\ and MASAYASU SUGIHARA \\ Department of Pharmacy, Tokyo Women's Medical College*2
}

(Received May 23, 1986)

The effects of various additives to protect Soya lecithin granules from moisture were investigated. Additives used were Adsolider-101®, Aerosil R-972 $\otimes$, Neusilin UFL-2 ${ }^{\circledR}$ and carnauba wax (mean diameter: $3 \mu \mathrm{m}$ ). Weight increase, angle of repose, aggregation rate and disintegration time of the lecithin granules were measured to evaluate the effect of additives on moisture protection and fluidity.

The hygroscopicity of the lecithin granules decreased with an increase in the amount of additives. Aerosil R-972 ${ }^{\circledR}$ was not adhered uniformly to the lecithin granules. The addition of $2-3 \%$ of Adsolider-101 ${ }^{\circledR}$ and Neusilin UFL-2® prevented the hygroscopicity and enhanced the fluidity of lecithin granules, though the appearance changed to white. It was considered that carnauba wax in the proportion of $5 \%$ was very useful for the prevention of hygroscopicity and the enhancement of fluidity of the lecithin granules.

Keywords_-lecithin; carnauba wax; hygroscopicity; effect of moisture protection

吸湿性医薬品の防湿は, 品質確保の面から必要不可久 であり, 病院薬局飞おいても種々の検討がなされている が1 3)，特飞調剤後の防湿対策は完全とはいい難い，現 在，包装材料の中でも比較的透湿度の低い高密度ポリ エチレンフィルム4) による散剤の包装が広く行われてい るが，その防湿効果は十分ではない，吸湿性の高いこと が知られている大豆レシチンは，血清脂質低下作用を有 乙，高脂質血症治療に古くから用いられているが，吸湿 により付着扣よび顆粒間の凝集が起こりやすく，ポリェ チレンフィルムによる包装を施しても分包時や服用の際 に著しい支障をきたしている，そこで，各種の添加剤を 加觉ることにより，防湿効果特よび流動性に与兄る影響 について検討し，さらにフィルムコーティングによる防 湿効果と比較検討した。

*1 日本病院薬鼡師会関東ブロック第15回学術大会(新 潟，1985年8月）で発表.

*2 東京都新宿区河田 町 8-1 : 8-1, Kawada-cho, Shinjuku-ku, Tokyo, 162 Japan

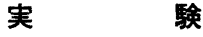

\section{1. 試料と保存条件}

大豆レシチンは，市販のソーヤ・レシチン顆粒 （大 日本製薬）の粒径14〜24メッシュのものを用いた．添加 剂は, 粉体物性の改善によく用いられる軽質無水ヶイ酸 の中で, 親水性のアドソリダー 101 および眯水性のアェ ロジル R-972，また比表面積が大きく賦形剂などにも用 いられるノイシリン UFL-2, 日局カルナウバロウの粉 砕品（平均粒径 $3 \mu \mathrm{m}$ ) を用いた。

試料は, 測定前に真空乾燥機中で24時間, 乾燥させた 後, 検体とした.レシチン顆粒と添加剂との混合は, 転 動混合により 5 分間行った。保存条件は, 温度 $30^{\circ} \mathrm{C}$, 相対湿度 $75 \%$ （塩化ナトリウム飽和デシケーター中）で 行い, 24時間保存後のるのを用いた.

\section{2. 測定方法}

1）重量增加率

試料の一定量（約 $1 \mathrm{~g}$ ）を秤量ビンに秤取し一定保存 
条件下に保存し，一定時間毎にその重量を測定して重量 増加率を求めた。

2）安息角

野上・杉原法6)により，保存前と保存 1 日後の值を測 定した.

\section{3）集合率 ${ }^{6}$}

小西式集合率測定器により行った。試料 $2 \mathrm{~g}$ を科取 し, 一定の高さから一定面積（8メッシュ）の網目上に 落下させ, 網目上に残った試料の重量との比を測定值と した.

\section{4) 崩壊度試験}

日局 10 の顆粒剤に対する崩壞試験法に準拠して行っ た。

5) フィルムコーティング

コーティング剤としてェチルセルロースおよびセラッ クを用い, 遠心流動型コーティング造粒装㯰により行っ た.

6）走查型電子顕微鏡写真

顆粒表面の状態は, 走查型電子顕微鏡 (SEM) を用い て観察した.

\section{結果 と考察}

\section{1) 重量增加东}

Fig. 1 に,レシチン顆粒にそれぞれアドソリダー101,
ノイシリン UFL-2, アェロジル R-972 を， 1，3，5， 10\%の割合で添加した時の重量増加率を示す. 各々の添 加剂を, 濃度の増大に伴ってその重量増加率は減少する 傾向に示し, 添加による防湿効果が認められた。

アドソリダーとノイシリンは，外観上，付着性がよ く，顆粒表面を白く均一に被っていることが肉眼で観察 された.一方，アェロジルは顆粒表面への付着が均一で ないため, 柾水性にもかかわらず重量増加率は他の $2 つ$ の添加剤と比較すると高くなっている。

Fig. 2 飞，カルナウバロウを添加した場合および添 加後 $85^{\circ} \mathrm{C}$ で 5 分間加熱し, 顆粒表面をコーティングし たものの重量増加率を示した．カルナウバロウも同様に 添加量の增加に従って重量增加率が減少し，その効果は アドソリダー，ノイシリン，アェロジルと比べて大きい と考えられる。

粒径が大きく異なる 2 種の粉体を混合した場合, 混合 方法や粉体の種類によっては，一方の粉体粒子に他方の 粉体粒子が付着して ordered mixture と呼ばれる混合 状態が得られることが報告されている7). これらの添加 剂による現象もこの ordered mixture が形成された結 果, レシチンの表面が改質されたものと考省られる.

また, 加熱処理した試料は, カルナウバロウが熔融し て顆粒表面を均一に被覆するため，一層吸湿性が妨げら れ, 添加濃度の増加により重量増加率が減少する傾向に
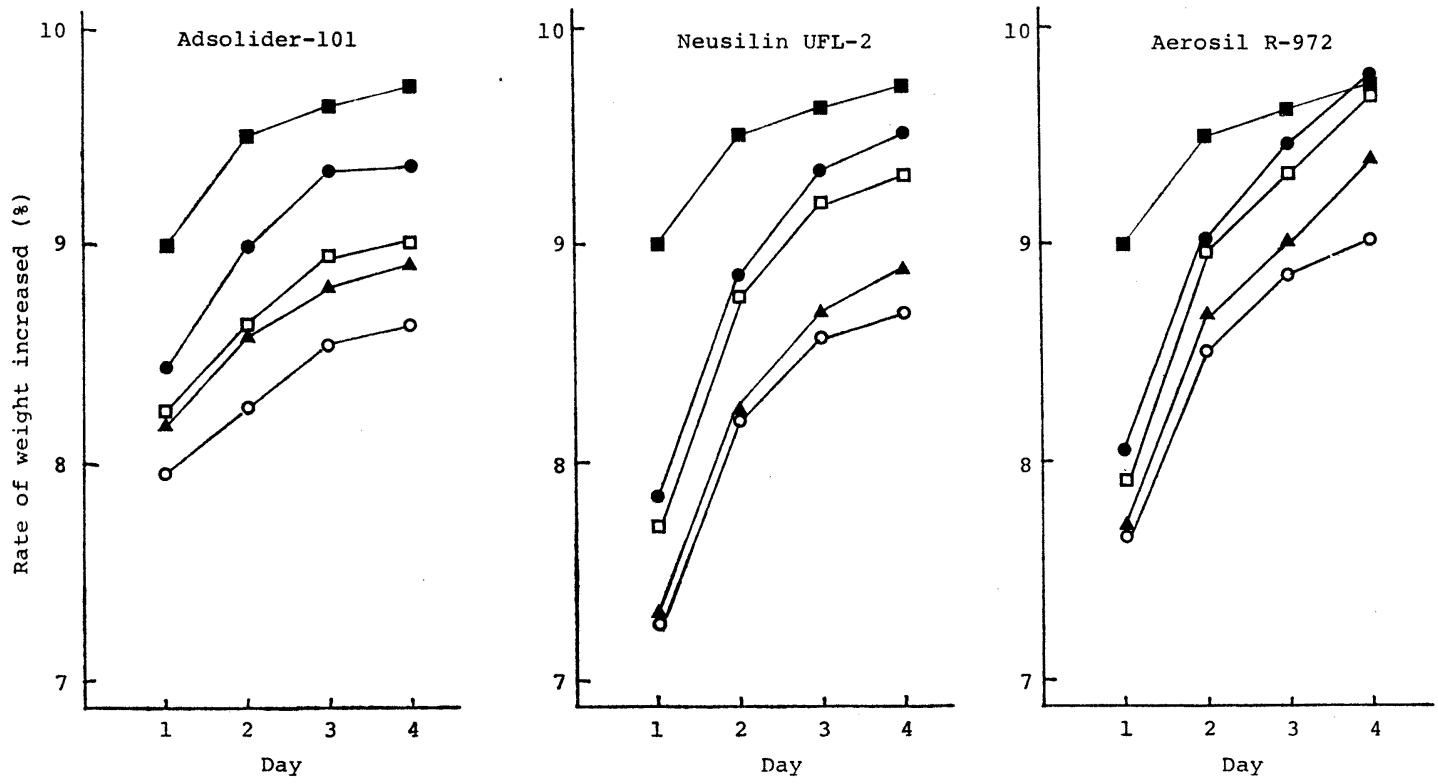

Fig. 1. Effect of Additives on Hygroscopicity of Lecithin ( $\mathrm{RH} 75 \%, 30^{\circ} \mathrm{C}, 24 \mathrm{hr}$ ) 
あったが，濃度差による著しい相違は見られなかった。 小石らは，粉体・粉粒体混合法により，乳糖顆粒の表面 をカルナウバロウにより被覆し，加熱8) または遠心回転 型混合器によっで）顆粒をカプセル化し，薬物放出の制 御などに応用している10)。

今回のレシチン顆粒へのカルナウバロウの加熱処理 は, 表面のベタッキ, 顆粒の凝集などの変化が 観察さ れ，実用面では難点があると考光られる。

\section{2）安息角}

Fig. 3 に，レシチン顆粒の安息角に及ぼす添加剂の 影響について示した．レシチン顆粒単独では $42^{\circ}$ 前後で あるが，保存後では約 $50^{\circ}$ に増加し，著しく流動性が低 下している. しかし添加剤の共存により，ノイシリン， アドソリダー, カルナウバロウの順に安息角が低下 し, とくにカルナウバロウにより著しい流動性の改善が 見られている，保存後も同様の傾向が見られた．またア エロジルは静電気の発生が著しく, 測定が不可能だっ た.

\section{3）集合率}

レシチン顆粒に各々の添加剤を $3 \%$ の濃度で用いた時 の集合率を Table 1 に示した. レシチン単独の場合と 比較して, 添加剤と共存しているレシチン顆粒はいずれ も集合率の低下が見られたが，保存前後で著しい差はみ られず，レシチン顆粒粒子間の㠜集を妨げていることが 示されている.

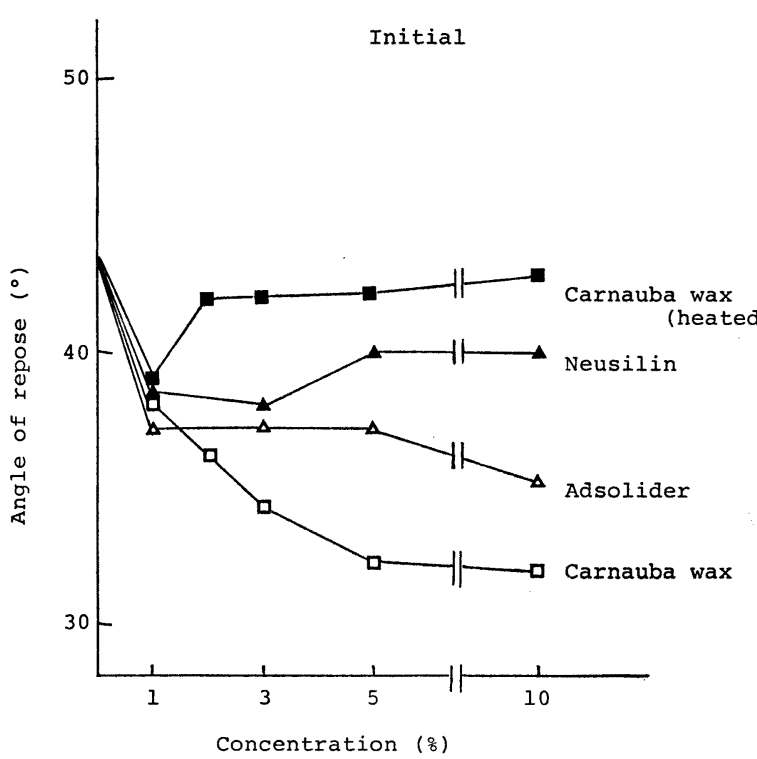

\section{4）崩壊度試験}

崩壊度試験の結果をFig. 4 飞示した。親水性のノイ

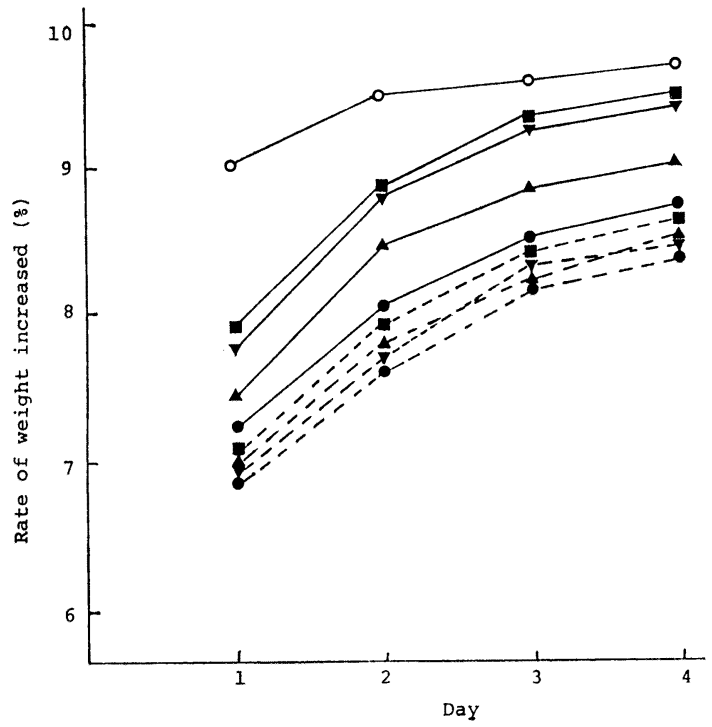

Fig. 2. Effect of Carnauba Wax on Hygroscopicity of Lecithin (RH $75 \%, 30^{\circ} \mathrm{C}$, 24hr)

$-\mathbf{D}-1 \% ;-\nabla-2 \% ;-\mathbf{-}-3 \%$;

$-\bullet-5 \% ;-\mathrm{O}-$ lecithin alone

solid line : carnauba wax (initial) dot line : carnauba wax (heated)

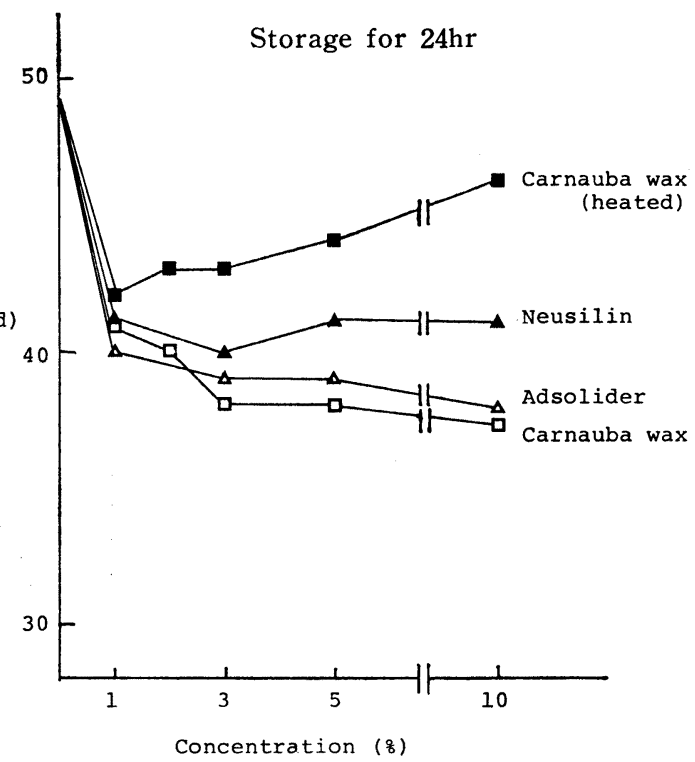

Fig. 3. Effect of Additives on Angle of Repose of Lecithin Initial and Stored at $\mathrm{RH} 75 \%, 30^{\circ} \mathrm{C}$ for $24 \mathrm{hr}$ 
Table 1. Effect of Additives of 3\% Concentration on Rate of Aggregation of Lecithin Initial and Stored for $24 \mathrm{hr}$ at $\mathrm{RH} 92 \%, 30^{\circ} \mathrm{C}$

\begin{tabular}{lcc}
\hline & $\begin{array}{c}\text { Initial } \\
(8)\end{array}$ & $\begin{array}{c}\text { Storage for } \\
\left(\frac{8}{8}\right)\end{array}$ \\
\hline Lecithin alone & 41.9 & 66.7 \\
Carnauba wax & 37.5 & 35.6 \\
$\begin{array}{c}\text { Carnauba wax } \\
\text { (heated) }\end{array}$ & 38.5 & 42.0 \\
$\begin{array}{c}\text { Adsolider-101 } \\
\text { Neusilin UFL-2 }\end{array}$ & 28.1 & 29.8 \\
Aerosil R-972 & 27.2 & 29.6 \\
Shellac & 30.0 & 30.6 \\
Ethyl cellulose & 1.7 & 26.3 \\
\hline
\end{tabular}

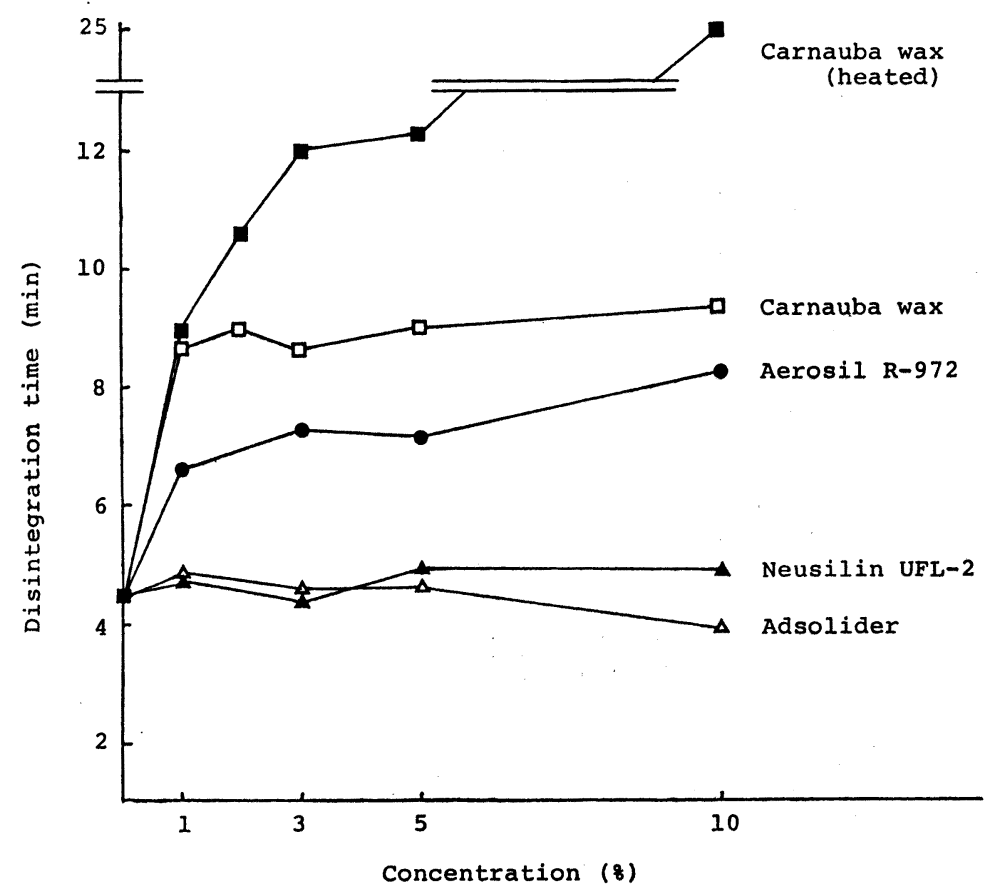

Fig. 4. Effect of Additives on Disintegration Time of Lecithin by JP X Disintegration Test for Granules

シリンおよびアドソリダーの添加では，レシチン顆粒単 独の場合と比べ崩壊時間に著しい差は見られなかった。 疎水性のアェロジル, カルナウバロウの添加では, 崩壊
時間の遅延がみられたが，すべて10分以内だった。カル ナウバロウを添加後加熱をしたものでは，他の添加剤と 比べ崩壊時間が長く，10\%では約25分であった。 また， 
顆粒表面をフィルムコーティングした試料は, セラック を用いた時は約30分で崩壊したが，エチルセルロースで は60分経過しても崩壊しなかった.

\section{5）走査型電子顕微鏡写真}

Photo. 1 に, 添加剤を $2 \%$ 添加した時の 50 倍に执大 した走査型電子顕微鏡写真を示した. 写真下の白線 1 本 は $1000 \mu \mathrm{m}$ を示している. a) のレシチンの顆粒表面 は非常に粗く，凹凸が激しいことが観察される，b）の ノイシリン, c）のアドソリダーは, 顆粒表面を均一に 白く被っていることがわかる。d）のアェロジルでは片 奇った付着がみられ $3 \%$ 添加でも同様の傾向がみられ た。

このことは, 期待した防湿効果が得られない一つの要 因であることを示唆している。

Photo. 2 は, 350 倍に拡大したもので, 白線 1 本は $100 \mu \mathrm{m}$ を示す， a ）はカルナウバロウ $5 \%$ 添加の場合 を示した．カルナウバロウの小さい粒子で全体的に被わ れていることが確認できる，3\%添加の場合には，5\% ほど完全に被覆されず, レシチンの表面がところどころ
露出していた。 b ) はカルナウバロウを $5 \%$ 添加し， さらに加熱したもので, 表面が滑らかでカルナウバロウ が愹融し，レシチン表面をコーティングしているよらに 見られるが, 表面の一部に粗い未処理の状態が認められ た. d) のエチルセルロース，c）のセラックによりフ イルムコーティングしたものは, 非常に滑らかに表面が 被われていることが確認された.

\section{結論}

今回，検討した添加剂のうち，アドソリダー，ノイシ リン，カルナウパロウは，顆粒表面への付着性が比較的 良好で, 均一に分散していたが，アエロジルは静電気が 発生しやすく, 混合器および包装紙などに付着し, 取り 扱いが難しいと考えられる。

エチルセルロース拈よびセラックによるフィルムコー ティングは, 防湿性・流動性に優れていたが, 崩壊が悪 く, また特殊な機器が必要なため簡単に調製ができない などの問題がある.またアドソリダー, ノイシリンでは 白色になるといら外観变化が認められるが，2３\%の a) lecithin alone

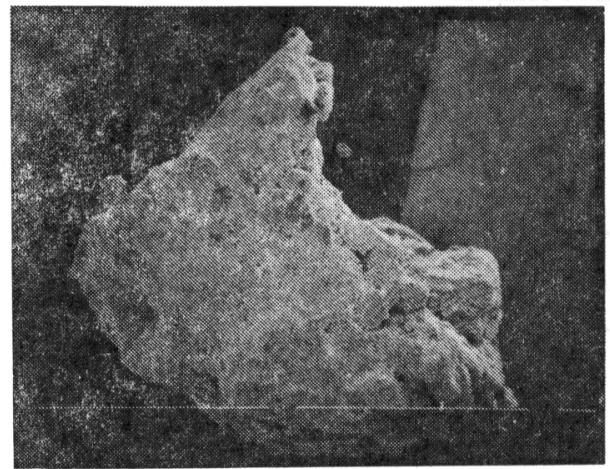

c) Adsolider-101

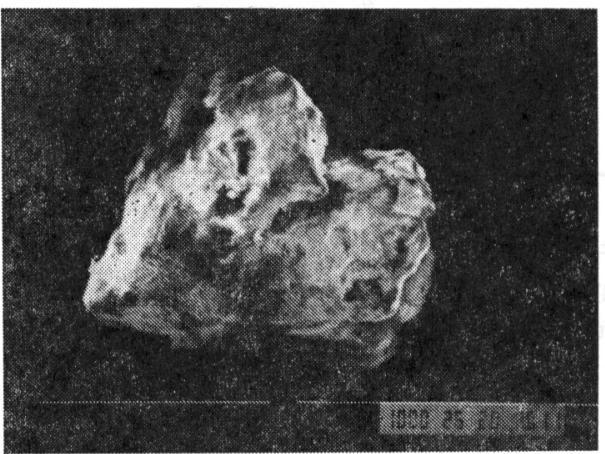

b) Neusilin UFL-2

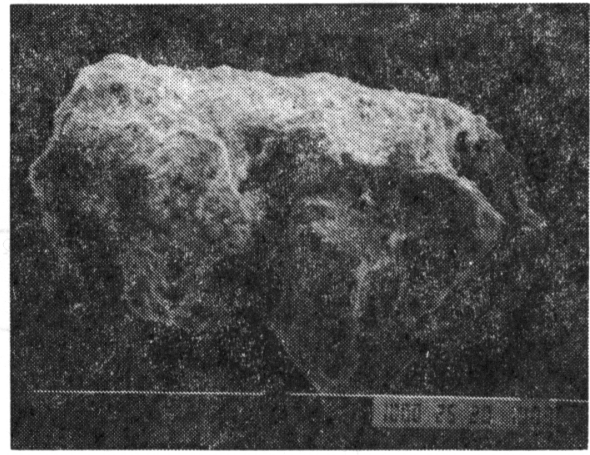

d) Aerosil R-972

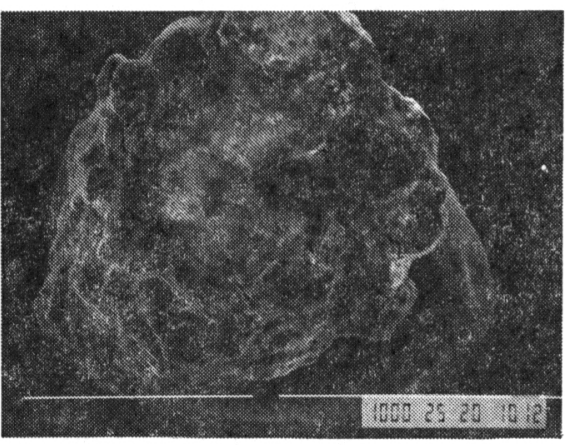

Photo. 1. Scanning Electron Micrographs of the Unmodified and Modified Lecithin Granules 
a) carnauba wax

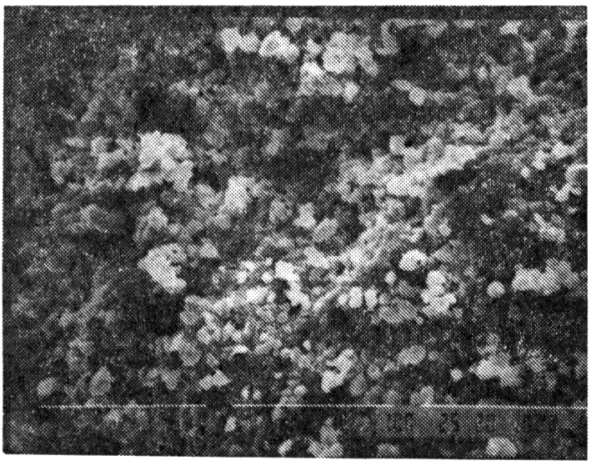

c) shellac

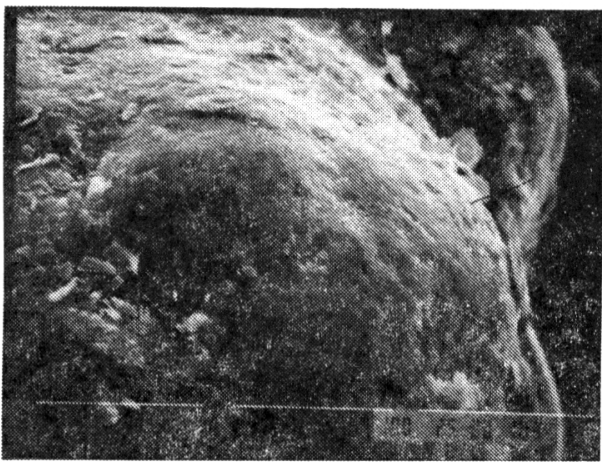

b) carnauba wax (heated)

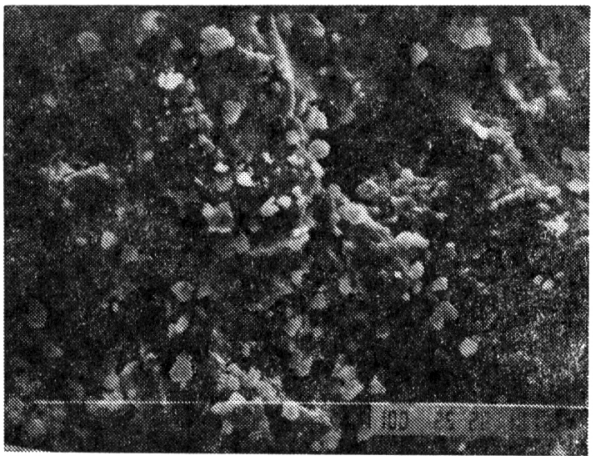

d) ethyl cellulose

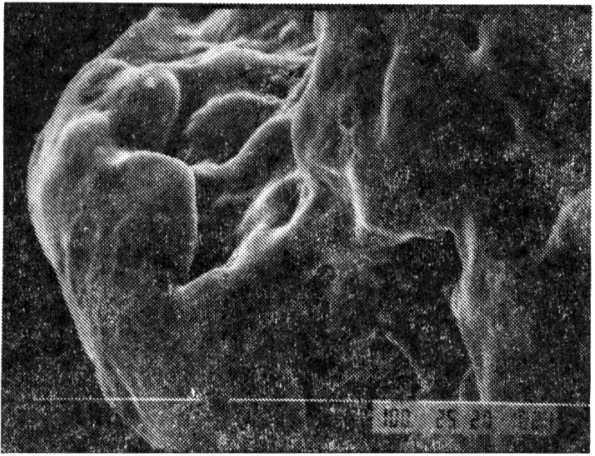

Photo. 2. Scanning Electron Micrographs of the Modified Lecithin Granules

添加で比較的よい防湿効果と流動性が得られた。カルナ ウバロウでは，外観变化は認められず，5\%添加で最も よい効果が得られ，添加剤として有用性が高いことが示 唆された。

謝辞 本研究にあたりで協力いただいた橋向りかり 氏，フロイント産業株式会社に深謝いたします。

\section{文献}

1）高山明, 越川富雄, 奥村勝彦, 堀了平, 上能伊公 雄，北沢式交：薬学雑誌，104，1174 (1984).

2）島川治己，小野彪，石田祐子，小原邦子，本城由 美子：病院薬学，6，276(1981)。

3）北沢式文, 小室徽雄, 伊藤洋子, 岡田寿太郎 : 薬 剂学, 36, 102 (1976).

4）日本包装技術協会編：“新・包装技術便覧”, 日本 生産性本部，東京，1971，p. 1085.

5）野上寿, 杉原正泰, 木村真太郎：薬剤学, 24, 103 (1964).

6）青木大, 福田友炤, 伊势村陽子, 古川美代子 : 薬 風学, 27, 189 (1967).

7) J. A. Staniforth, J.E. Rees, F. K. Lai, J.A. Hersey : J. Pharm. Pharmacol., 34, 141(1982).

8）矢野行一, 石坂隆史, 小石真純: 第 4 回製㓣の安 定化とその評価法シンポジウム講演要旨集, p. 79 (1981).

9) M. Koishi, K. Yano, T. Ishizaka : J. Pharm. Dyn., 5, S-9 (1982) ; T. Nakajima, T. Ishizaka, M. Koishi : J. Pharm. Dyn., 7, S-21 (1984).

10）石坂隆史, 山田真由美, 矢野行一, 小石真純 : 薬 剂学, 45, 193 (1985). 